\title{
THE INVESTMENT OPPORTUNITY SET AND ITS PROXY VARIABLES*
}

\author{
Tim Adam \\ Massachusetts Institute of Technology \\ Vidhan K. Goyal \\ Hong Kong University of Science \& Technology
}

August 6, 2007

\footnotetext{
* We thank Andrew Carverhill, K. C. Chan, Kalok Chan, Sudipto Dasgupta, Lynn Doran, Jin Chuan Duan, Joseph Fan, Gerry Gay (the editor), Chuan Yang Hwang, Stephen Penman, Dan Rogers; seminar participants at the University of Oregon and the Hong Kong University of Science and Technology; participants at the annual meetings of APFA and the German Finance Association; and especially an anonymous referee and Tjalling von der Goot for helpful comments. Funding for this project was provided by the Hong Kong Research Grants Council under Grant \# HKUST6008/99H.
} 


\begin{abstract}
We use a real options approach to evaluate the performance of several proxy variables for a firm's investment opportunity set. The results show that, on a relative scale, the market-to-book assets ratio has the highest information content with respect to investment opportunities. Although both the market-to-book equity and the earnings-price ratios are related to investment opportunities, they do not contain information that is not already contained in the market-to-book assets ratio. Consistent with this finding, a common factor constructed from several proxy variables does not improve the performance of the market-to-book assets ratio.
\end{abstract}

JEL Classification: G31, D92, L72, C52 


\section{Introduction}

Investment opportunities play an important role in corporate finance. The mix of assets in place and investment opportunities affects a firm's capital structure, the maturity and covenant structure of its debt contracts, its dividend policy, its compensation contracts, and its accounting policies (e.g., Smith and Watts 1992; Rajan and Zingales 1995; Billett, King and Mauer 2007). It is not surprisingly that measures of a firm's investment opportunity set feature prominently in the empirical corporate finance literature. As investment opportunities are typically unobservable by outsiders, a common practice is to rely on proxy variables. However, we know little about how well these proxy variables perform, which can be largely attributed to the difficulty in measuring investment opportunities. ${ }^{1}$ Given that proxies are widely used in the literature, Baker (1993) argues that this lack of understanding is an important problem in empirical corporate finance research.

In this article, we examine the relative performance of the most commonly used proxy variables in an industry in which firms' major investment opportunities are observable by outsiders. The Securities and Exchange Commission (SEC) requires mining firms to disclose information about the nature, quality, and magnitude of their mineral deposits. ${ }^{2}$ To our knowledge, no other industry discloses similarly detailed information about their investment opportunities. These disclosure rules and the existence of a well-established option pricing model

\footnotetext{
${ }^{1}$ Chung and Pruitt (1994), Perfect and Wiles (1994) and DaDalt, Donaldson, and Garner (2003) compared different ways of estimating Tobin's $q$. Recently, Erickson and Whited (2006) examined the measurement quality of different proxies for $q$. Kallapur and Trombley (1999) examined the performance of various investment opportunity proxies by measuring investment opportunities by the realized growth in firms' book values of equity, assets, and sales. Goyal, Lehn, and Racic (2002) examined how the proxies change when there is an exogenous shock to the investment opportunity set.

${ }^{2}$ See SEC rule 504, Sections 229.801 and 317.477.
} 
to value investment opportunities as real options present a unique opportunity to evaluate the performance of investment opportunity proxy variables. We evaluate four of the most commonly used proxy variables for a firm's investment opportunity set: (1) the market-to-book assets ratio (MBA ratio), (2) the market-to-book equity ratio (MBE ratio), (3) the earnings-price ratio (EP ratio), and (4) the ratio of capital expenditures over the net book value of plant property and equipment (CAPX/PPE ratio). Because we can measure investment opportunities in the mining industry using a real option approach, we can examine the correlation of the proxy variables with the real option measures of a firm's investment opportunity set.

We find the MBA ratio to be the best performing proxy. The three market-based proxies, that is the two market-to-book ratios and the EP ratio, are significantly correlated with firms' investment opportunities. The purely accounting-based proxy, the CAPX/ PPE ratio, also appears to be positively related to the value of investment opportunities, but this relation is not robust. Among the market-based proxies, the MBA ratio has the highest information content with respect to investment opportunities. Neither the MBE ratio nor the EP ratio provides incremental information beyond that already contained in the MBA ratio. Extracting a common factor from the four proxies does reduce some noise, but it also reduces the information content with respect to investment opportunities. This approach does not prove to be beneficial in our sample.

\section{The Investment Opportunity Set and Its Proxy Variables}

Myers (1977) divides the market value of a firm into two parts: the present value of assets already in place and the value of investment opportunities. The fundamental difference between the two is that the value of investment opportunities depends on future discretionary investments, 
whereas the value of assets in place does not. This section describes the four most commonly used proxy variables for a firm's investment opportunity set.

\section{The Market-to-Book Assets Ratio}

The ratio of the market value of assets to the book value of assets (the MBA ratio), or the closely related measure, Tobin's $q$, is perhaps the most commonly used proxy for investment opportunities. ${ }^{3}$ The book value of assets is a proxy for assets in place, whereas the market value of assets is a proxy for both assets in place and investment opportunities. Thus, a high MBA ratio indicates that a firm has many investment opportunities relative to its assets in place.

Although theoretically sound, the MBA ratio has several empirical shortcomings as a proxy for the investment opportunity set. First, the market value of assets requires an estimation of the market value of debt. Debt is often not publicly traded. Second, the book value of assets does not necessarily equal the replacement value of assets. Third, the MBA ratio (or Tobin's $q$ ) is also used as a proxy for many other variables such as corporate performance, intangibles, the quality of management, agency problems, and firm value. Thus, its value as a proxy for growth opportunity remains unclear.

\section{Market-to-Book Equity Ratio}

A second commonly used proxy for investment opportunities is the market value of equity divided by the book value of equity (the MBE ratio). See Chung and Charoenwong (1991) Collins and Kothari (1989), Graham and Rogers (2002), and Lewellen, Loderer, and Martin (1987) for usage of this proxy. The market value of equity measures the present value of all future cash flows to equity holders, from both assets in place and future investment 
opportunities, whereas the book value of equity represents the accumulated value generated from existing assets only. Therefore, the MBE ratio measures the mix of cash flows from assets in place and future investment opportunities.

An empirical advantage of the MBE ratio over the MBA ratio is that its construction does not require information on the market value of debt, nor does it require the estimation of replacement values. However, like the MBA ratio, the MBE ratio proxies for other variables too, such as corporate performance. Another concern is that the MBE ratio is affected by leverage. Much of the capital structure literature argues that leverage itself is a function of investment opportunities (e.g., Rajan and Zingales, 1995; Frank and Goyal 2003, 2005). If low-growth firms choose more debt in their capital structures, then their MBE ratios would be higher than what would be implied by growth opportunities alone. Finally, a concern with the MBE ratio is that firms with negative equity values must be omitted from the analysis since negative MBE ratios are not meaningful in measuring investment opportunities.

\section{Earnings-Price Ratio}

A third commonly used proxy of investment opportunities is the earnings-price ratio (the EP ratio) or its inverse, the price-earnings ratio. Chung and Charoenwong (1991) argue that a higher EP ratio indicates that a larger proportion of equity value is attributable to assets in place relative to growth opportunities. This inference assumes that current earnings proxy for cash flows received from assets in place, whereas a firm's market value of equity reflects the present value of all future cash flows, that is, cash flows from assets in place and future investment opportunities.

\footnotetext{
${ }^{3}$ Tobin's $q$ is defined by the ratio of the market value of assets over the replacement value of assets. Perfect and Wiles (1994) show that Tobin's $q$ and the MBA ratio are highly correlated (the correlation coefficient is about 0.96 ).
} 
An empirical advantage of the EP ratio is that its calculation, like that of the MBE ratio, does not rely on the market value of debt, which is typically not observable. A disadvantage, however, is that the EP ratio is not a meaningful measure of investment opportunities if firms report zero or negative earnings. In addition, the price-earnings ratio has several other interpretations in the literature. Penman (1996) points out that it has been interpreted as an earnings growth indicator, as a risk measure, or as an earnings capitalization rate. Finally, the EP ratio is also affected by leverage. Finally, Penman (1996) reports low correlations between the MBE ratio and the EP ratio. A lower EP ratio does not always indicate that a firm has good investment opportunities because current earnings sometimes deviate temporarily from their long-run expected values.

\section{Capital-Expenditures-to-Net-Plant-Property-and-Equipment Ratio}

A fourth proxy for investment opportunities is the ratio of a firm's capital expenditures divided by net plant property and equipment at the beginning of the period (the CAPX/PPE ratio). The motivation for this variable is that capital expenditures are largely discretionary and lead to the acquisition of new investment opportunities. For example, by developing a mineral reserve, a firm acquires the option to extract the metal. Firms that invest more acquire more investment opportunities relative to their existing assets than do firms that invest less. ${ }^{4}$

In summary, all four proxy variables have their own particular advantages and disadvantages. Both market-to-book ratios proxy for variables other than the investment opportunity set. The MBE ratio is endogenous to a firm's leverage decision, while the MBA ratio cannot be calculated precisely if the market value of a firm's debt differs significantly from its book value. Similarly, the transitory component of earnings reduces the information content of the EP ratio

We therefore do not distinguish between Tobin's $q$ and the MBA ratio.

${ }^{4}$ A related measure is the research intensity, defined by $R \& D$ expenditures divided by total assets or sales. 
as a proxy for investment opportunities. Capital expenditures may or may not lead to the acquisition of investment opportunities, and it is not clear whether the relationship between expenditures and the value of the acquired investment options is even linear. Thus, it is an empirical issue which investment opportunity proxy performs better and whether a combination of several proxies could improve the performance.

\section{Investment Opportunities in the Mining Industry}

Mining operations consist of the following three stages: exploration, development, and production. The exploration stage includes prospecting, sampling, mapping, drilling and other activities associated with searching for new mineral deposits. Any newly discovered deposits are first classified as resources. Further test drillings must be undertaken to define the geology of the deposit more accurately and to test whether extraction is economically feasible. Once economic feasibility has been established, a resource is reclassified as a reserve. The mine then enters the development stage, which consists of building the mining facilities, processing plants, and roads, and sinking the mineshafts (for underground mines), or removing a first layer of waste rock (for open pit mines). Upon completion of the initial development of the mine, the production stage begins. During this stage, a firm needs to develop the rest of the mine continuously to make all areas of the ore body accessible for extraction.

Investment opportunities exist in all three stages of mining operations. They consist primarily of (1) the option to develop and extract a mineral reserve (the production stage), (2) the option to develop a completely undeveloped reserve (the development stage), and (3) the option to reclassify a resource to a reserve through further exploration work (the exploration stage). Given the discretionary nature of these investment opportunities, they are best regarded and valued as 
options. In the literature, they are often referred to as real options. The options' exercise prices represent the future investments required to acquire the assets.

We value two major investment opportunities in the mining industry: the option to extract a known mineral reserve, and the option to reclassify a resource as a reserve and to extract the reserve. $^{5}$ To value the option to extract the reserve, we use Brennan and Schwartz's (1985) method, which builds on established option-pricing techniques. ${ }^{6}$ The valuations depend on the six well-known option pricing parameters for commodity options: the metal spot price, the volatility of the metal, the net convenience yield (convenience yield less storage costs), the riskfree rate, the strike price of the option, and the option maturity. An example illustrating our valuation together with a description of data sources and estimation method is given in Appendix A.

To value resources, we use the Hotelling valuation principle (mining firms do not disclose sufficient information for option valuation techniques). The information available on resources includes the size of the resource, the average metal concentration in the ground (metal grade), and whether extraction requires an open-pit or underground mine. According to the Hotelling principle, the value of a metal resource is the product of the resource size and the difference between the current metal price and the expected extraction and development costs. Appendix A also provides an example illustrating our valuation of resources.

\footnotetext{
${ }^{5}$ The value of reserves and resources represent a mining firm's major assets. Other investment opportunities may also exist but they are difficult to value due to insufficient data. For example, firms have the option to explore for new deposits, the option to delay the development or production stages, the option to increase the production capacity, and the option to open or close mines.

${ }^{6}$ Papers that have adopted the real option framework for valuing natural resources include Siegel, Smith, and Paddock (1987), Trigeorgis (1990), Kemna (1993), and Smith and McCardle (1999).
} 


\section{Sample and Descriptive Statistics}

We constructed our sample by first identifying all firms listed on the Compustat tapes (i.e., the Canadian, U.S. industrial, full coverage, and research tapes) for the year 1996 with a twodigit Standard Industrial Classification code of 10 (North American metal mining industry). We then exclude firms that do not report ownership of any metal reserves or metal resources and those that produce only specialty metals, such as molybdenum, cobalt, uranium, etc., for which sufficient financial data is not available. This resulted in a final sample consisting of 90 mining companies operating 405 different mines, covering 8 years from 1989 to 1996 for a total of 444 firm-years. Appendix B lists the company names included in the final sample. These companies produce both precious metals (gold and silver) and base metals (copper, lead, nickel, and zinc). Gold producing mines account for about $78 \%$ of the sample.

The four investment opportunity proxies are constructed using the Compustat data following standard definitions. Negative values are treated as missing.

MBA ratio $=($ share price $(\# 199) \times$ shares outstanding $(\# 54)+$ preferred stock $(\# 10)+$ debt in current liabilities (\#34) + long-term debt (\#9) - deferred taxes and investment tax credit (\#35)) / book value of assets (\#6)

MBE ratio $=$ share price $(\# 199) \times$ shares outstanding $(\# 54) /$ common equity $(\# 60)$

EP ratio $=$ earnings per share $(\# 58) /$ share price $(\# 199)$.

$\mathrm{CAPX} / \mathrm{PPE}$ ratio $=$ capital expenditures $(\# 128) /$ net plant property and equipment at the beginning of the fiscal year (\#8) 
Table 1 reports descriptive statistics on the book and market values of assets, the two realoption measures (value of reserves and resources), and the four investment opportunity proxies. The descriptive statistics show that the mining industry consists of a few large firms and many small producers. The average values of assets (in both book and market value terms) are substantially larger than the median. Reserves contribute significantly more to the value of investment opportunities than do resources. In fact, most firms do not report any resources.

The data also show that although we examine a single industry, substantial cross-sectional variation exists in the four proxy variables. For example, the tenth percentile of the MBA ratio in our sample has a value of 0.91 while the ninetieth percentile has a value of 3.44 . We also find that the sample distribution of the investment opportunity proxies in the mining industry is similar to that of a broader industry segment. The tenth, fiftieth and the ninetieth percentiles for all non-financial and non-utility firms from the Compustat universe are about $0.88,1.48$, and 4.12, respectively, similar to the distribution for the mining firms. Hence, in terms of investment opportunity proxies, our sample of mining firms appears to be comparable to a random sample drawn from the non-financial, non-utility sectors.

Table 2 reports correlation coefficients between the investment opportunity proxy variables and the two real options measures. Among the four proxy variables, the MBA ratio and the MBE ratio have the highest correlation with each other $(\rho=0.70)$. The negative correlation of the EP ratio with the two market-to-book ratios is consistent with the EP ratio being an inverse measure of investment opportunities. However, the correlations involving the EP ratio are significantly smaller in magnitude than between the two market-to-book ratios. The CAPX/PPE ratio is positively correlated with the two market-to-book ratios, but these correlations are also small. The EP ratio is uncorrelated with the CAPX/PPE ratio. These differences in correlations appear 
surprising given that all four proxies are supposed to measure the value of investment opportunities.

The real options value of reserves is significantly correlated with the MBA, the MBE, and the EP ratios, but uncorrelated with the CAPX/PPE ratio. The correlation is strongest with the MBA ratio $(\rho=0.28)$. The value of resources is significantly correlated with the MBA ratio $(\rho=$ 0.26) but not with any of the other proxy variables. Finally, the correlation between the value of reserves and resources is statistically insignificant, indicating that reserves and resources represent distinct investment opportunities. ${ }^{7}$

\section{The Relative and Incremental Information Content}

This section examines the incremental and relative information contents of each proxy with respect to the value of reserves. Incremental comparisons are useful in determining if one measure provides information beyond that provided by another. They apply when one measure is given and the inclusion of another measure is considered. Relative comparisons are useful in determining which measure has the greatest information content among several measures. They are applicable when making mutually exclusive choices among alternatives.

Figure I about here.

For example, Figure I shows the relation between two proxy variables, A and B, with respect to their information contents. In both cases, B has greater relative information content than A has. In Case I, A has incremental information content beyond B, whereas in Case II it does not.

\footnotetext{
${ }^{7}$ The samples that include resources are substantially smaller - often too small to draw meaningful statistical inferences. Subsequent analysis therefore focuses only on the value of reserves.
} 
In the latter case, it is sufficient to use only one proxy, i.e., the variable with the highest relative information content, whereas, in Case I, both proxies should be used.

\section{Tests of the Incremental Information Content}

Table 3 reports results from regressions of the value of reserves on each of the four proxy variables. Consistent with the correlations reported in Table 2, the reserves are positively related to the MBA and the MBE ratios and are negatively related to the EP ratio. They are unrelated to the CAPX/PPE ratio. Note that the $\mathrm{R}^{2}$ is highest for the MBA regressions, followed by MBE, the EP ratio and finally the CAPX/PPE ratio. A comparison of the $\mathrm{R}^{2} \mathrm{~s}$ suggests that MBA has the highest information content (formal tests of relative information contents are presented in the next section).

Tests of incremental information contents examine if other investment opportunity proxies (MBE, the EP ratio and the CAPX/PPE ratio) have information about reserves beyond that contained in the MBA ratio. In Column (5), we therefore add the MBE ratio, the EP ratio and the CAPX/PPE ratio to the regression specification reported in Column (1). Although the sample size reduces considerably, the results show that none of the other proxies adds to the information contained in the MBA ratio. The sign on the MBE ratio is significant but is reversed due to the high correlation with the MBA ratio. In column (6), we exclude the EP ratio to increase the sample size, but there is no difference in the conclusion about the lack of incremental information in the MBE, and the EP and the CAPX/PPE ratios.

Overall, these results indicate that the MBA ratio has the highest information content with respect to firms' investment opportunities. Although both the MBE and the EP ratios are related to investment opportunities, they do not contain information about investment opportunities that 
is not already in the MBA ratio. The CAPX/PPE ratio appears to be unrelated to investment opportunities. $^{8}$

\section{Tests of the Relative Information Content}

The tests of the relative information content examine which of the four proxies (MBA, MBE, $\mathrm{EP}$, or $\mathrm{CAPX} / \mathrm{PPE}$ ) has the greatest association with the value of reserves. Biddle, Seow, and Siegel (1995) developed a test based on a comparison of $R^{2} s$. To implement this test, we regress the value of reserves on each proxy variable and compute a lack-of-fit measure defined as the average of the sum-of-the-squared residuals plus the sum-of-the-squared prediction errors. The null hypothesis used to compare the relative information contents of two proxies is that their relative lack-of-fit measures are equal. The hypothesis is examined using a Wald test of estimated coefficients and their heteroskedasticity-adjusted variance-covariance matrix. Biddle et al. show that this method for assessing relative information contents compares favorably with alternative tests provided by Davidson and MacKinnon (1981). Under usual regularity conditions (uncorrelated homoskedastic errors), it is finite sample exact, generalizes to any number of predictor variables, and can be used in conjunction with White's correction for heteroskedastic errors.

Panel A of Table 4 presents the $\mathrm{R}^{2}$ s from separate regressions of the value of reserves/assets ratio on each of the four proxy variables. The MBA ratio has the highest $\mathrm{R}^{2}(0.32)$, followed by the MBE ratio (0.05), the EP ratio (0.02), and finally the CAPX/PPE ratio (0.00). The p-values from two-tailed statistical tests of relative information contents are shown in the parentheses for

\footnotetext{
${ }^{8}$ To address concerns that residuals may be correlated across years or correlated across different firms in a given year, we replicate our analysis using clustered standard errors where we cluster on both firm and years. Our conclusions are not sensitive to this alternative specification.
} 
each of the six possible pair-wise comparisons. The MBA regression has a larger $\mathrm{R}^{2}$ than any of the other three proxy variables has. The $\mathrm{R}^{2} \mathrm{~s}$ from the MBE, the EP and the CAPX/PPE regressions are not significantly different from each other.

In Panel $\mathrm{B}$, we report the pairwise $\mathrm{R}^{2} \mathrm{~s}$ from regressions of reserves on proxy variables but use broader samples that require non-missing observations only for the pair of proxy variables under consideration. The MBA regression has a larger $\mathrm{R}^{2}$ than those from regressions of other proxy variables. In sub-samples where both MBA and MBE are non-missing, the MBA regression has a larger $\mathrm{R}^{2}$ than does the MBE regression ( $\mathrm{p}$-value $=0.06$ ). In sub-samples where both MBA and EP are non-missing, again the MBA regression has a larger $\mathrm{R}^{2}$ than does the EP regression ( $p$-value $=0.00$ ). The MBE regression also produces larger $\mathrm{R}^{2} \mathrm{~s}$ compared with those from the EP regression but the differences are not statistically significant. The CAPX/PPE regression explains none of the variation in reserves.

In summary, these results imply that the MBA ratio has the highest information content of the four proxy variables with respect to investment opportunities. By contrast, the CAPX/PPE ratio appears to be a poor proxy for investment opportunities. We can conjecture several reasons for the poor performance of the CAPX/PPE ratio. First, capital expenditure is a policy decision and the correlation between capital expenditures and investment opportunities depends on how well firms respond to investment opportunities. Asymmetric information and agency costs result in capital expenditures responding to financial variables such as cash flows and leverage. ${ }^{9}$ Second, capital expenditures may be lumpy and firms may not be able to increase investment

\footnotetext{
${ }^{9}$ The finding that capital expenditures respond to both Tobin's $q$ and cash flows is documented in a large body of literature starting with Fazzari, Hubbard and Peterson (1988). Much of this literature has argued that the sensitivity of investment to cash flows is consistent with information asymmetry, which makes external finance costly. However, this interpretation of the findings remains controversial.
} 
when growth opportunities improve or decrease planned capital expenditures when investment opportunities decline.

\section{Performance of a Common Factor Extracted from the Proxy Variables}

This section examines if a common factor extracted from the four proxy variables would improve the performance over the MBA ratio alone. This common factor approach is also of independent interest as it has been adopted in several earlier papers as a way to improve on investment opportunity proxies (see Gaver and Gaver (1993), Baber, Janakiraman, and Kang (1996), Jaggi and Gul (1999), and Chen (2003)). Factor analysis is a statistical technique for reducing the number of variables in an analysis by describing the linear combination of the variables that contain most of the information. We have used several different extraction methods, which yielded qualitatively identical results, and therefore report results based on the iterated principal factors method only.

The sample sizes vary depending on the choice of proxy variables used in the analysis. We therefore present results for three different combinations of proxy variables (1) all four proxy variables (MBA, MBE, EP, and CAPX/PPE ratio), (2) the three proxy variables without the EP ratio, and (3) the three proxy variables without the CAPX/PPE ratio. For each of these three samples, we find that most of the explained variance can be attributed to the first factor. Panel A of Table 5 presents correlations between the proxy variables and the first factor. In each case, both the MBA and the MBE ratios exhibit large positive factor loadings. The loadings on the EP ratio and the CAPX/PPE ratio are relatively smaller, but both have the expected sign, negative on the EP ratio and positive on the CAPX/PPE ratio. 
Panel B presents results from tests of the relative information content of the common factor over the MBA ratio. The question is if the common factor has a higher association with reserves than with the MBA ratio. Surprisingly, we find that the common factor performs worse than the MBA ratio. The $R^{2}$ in a regression of reserves on the common factor is 0.22 . In contrast, the $R^{2}$ from a regression of reserves on the MBA ratio alone is significantly larger at 0.32 (the Waldtest has a $\chi^{2}$ of 9.14 with a p-value of 0.00 ). Panel $\mathrm{C}$ presents results from tests of the relative information content of the common factor based on three proxy variables excluding the EP ratio. In this sample, we also find no evidence that the common factor has greater relative information content compared with the MBA ratio. The $\mathrm{R}^{2} \mathrm{~s}$ are not significantly different from each other. In Panel D, we test for the relative information content of the common factor from MBA, MBE and the EP ratio. The results, once again, suggest that the common factor has a lower association with reserves than the MBA ratio has.

\section{Conclusions}

Despite the important role that investment opportunities play in the corporate finance literature, there is no consensus on how to measure the value of a firm's investment opportunity set. The problem is that firms' investment opportunities are generally unobservable by outsiders. Researchers are therefore forced to rely on proxy variables, but little is known about the performance of these proxies. The metal mining industry, in which investment opportunities are relatively well defined and transparent, represents an exception and offers a unique opportunity to measure the performance of the proxy variables for the investment opportunity set.

We estimate the value of the investment opportunities of metal mining firms using a real options approach, and compare these values with four of the most commonly used proxy 
variables. On a relative scale, the market-to-book assets ratio appears to be the best variable to proxy for a firm's investment opportunities along several dimensions. It has the highest information content of all proxies with respect to investment opportunities. Although both the market-to-book equity and earnings-price ratios are related to investment opportunities, they do not contain information about investment opportunities that is not already contained in the market-to-book assets ratio. Consistent with this finding, our results indicate that extracting a common factor from several proxies is unlikely to improve upon the performance of the marketto-book assets ratio. Finally, the ratio of capital expenditures over plant property and equipment emerged as the poorest proxy for the investment opportunity set. 


\section{References}

Baber, W., S. Janakiraman, and S. Kang, 1996, Investment opportunities and the structure of executive compensation, Journal of Accounting and Economics 21, 297-318.

Baker, G.P., 1993, Growth, corporate policies, and the investment opportunity set, Journal of Accounting and Economics 16, 161-165.

Biddle, G.C., G.S. Seow, and A.F. Siegel, 1995, Relative versus incremental information content, Contemporary Accounting Research 12, 1-23.

Billett, M., D. King, and D. Mauer, 2007, The effect of growth opportunities on the joint choice of leverage, maturity, and covenants, Journal of Finance 62, 697-730.

Brennan, M. and E. Schwartz, 1985, Evaluating natural resource investments, Journal of Business 58, 135-157.

Chen, C.Y., 2003, Investment opportunities and the relation between equity values and employees' bonus, Journal of Business Finance and Accounting 30, 941-973.

Chung, C.H. and S.W. Pruitt, 1994, A simple approximation of Tobin's q, Financial Management 23, 70-74.

Chung, K. and C. Charoenwong, 1991, Investment options, assets in place, and the risk of stocks, Financial Management 20, 21-33.

Collins, D.W. and S.P. Kothari, 1989, An analysis of intertemporal and cross-sectional determinants of earnings response coefficients, Journal of Accounting and Economics 11, $143-181$.

DaDalt, P.J., J.R. Donaldson and J.L. Garner, 2003, Will any q do?, Journal of Financial Research 26, 535-551.

Davidson, R. and J. MacKinnon, 1981, Estimation and Inference in Econometrics (Oxford University Press, New York).

Dobra, J.L., 1997, The U.S. gold industry 1996, Nevada Bureau of Mines and Geology, Special Publication 21.

Erickson, T. and T.M. Whited, 2006, On the accuracy of different measures of Q, Financial Management 35, 5-33.

Fazzari, S., G. Hubbard, and B. Petersen, 1988, Financing constraints and corporate investment, Brookings Papers on Economic Activity 1, 141-206.

Frank, M.Z. and V.K. Goyal, 2003, Testing the pecking order theory of capital structure, Journal of Financial Economics 67, 217-248. 
Frank, M.Z. and V.K. Goyal, 2005, Capital structure decisions, University of Minnesota and Hong Kong university of Science and Technology, working paper.

Gaver, J.J., and K.M. Gaver, 1993, Additional evidence on the association between the investment opportunity set and corporate financing, dividend and compensation policies, Journal of Accounting and Economics 16, 125-160.

Goyal, V.K., K. Lehn, and S. Racic, 2002, Growth opportunities and corporate debt policy: The case of the U.S. defense industry, Journal of Financial Economics 64, 35-59.

Graham, J.R. and D.A. Rogers, 2002, Do firms hedge in response to tax incentives?, Journal of Finance 57, 815-839.

Jaggi, B. and F.A. Gul, 1999, An analysis of joint effects of investment opportunity set, free cash flows, and size of corporate debt policy, Review of Quantitative Finance and Accounting 12, 371-381.

Kallapur, S. and M. Trombley, 1999, The association between investment opportunity set proxies and realized growth, Journal of Business Finance \& Accounting 26, 505-519.

Kemna, A.G.Z., 1993, Case studies on real options, Financial Management 22, 259-270.

Lewellen, W.G., C. Loderer, and K. Martin, 1987, Executive compensation and executive incentive problems: An empirical analysis, Journal of Accounting and Economics 9, 287310.

Myers, S., 1977, Determinants of corporate borrowing, Journal of Financial Economics 5, 147 175.

Penman, S., 1996. The articulation of price-earnings ratios and market-to-book ratios and the evaluation of growth, Journal of Accounting Research 34, 235-259.

Perfect, S.B. and K.W. Wiles, 1994, Alternative constructions of Tobin's q: An empirical comparison, Journal of Empirical Finance 1, 313-341.

Rajan, R.G. and L. Zingales, 1995, What do we know about capital structure? Some evidence from international data, Journal of Finance 50, 1421-1460.

Siegel, D.R., J.L. Smith, and J.L. Paddock, 1987, Valuing offshore oil properties with option pricing models, Midland Corporate Finance Journal 5, 22-30.

Smith, C.W., Jr. and R.L. Watts, 1992, The investment opportunity set and corporate financing, dividends, and compensation policies, Journal of Financial Economics 32, 262-292.

Smith, J.E. and K.F. McCardle, 1999, Options in the real world: lessons learned in evaluating oil and gas investments, Operations Research 47, 1-15. 
Trigeorgis, L., 1990, A real-options application in natural-resource investments, in F.J. Fabozzi, ed.: Advances in Futures and Options Research Vol. 3 (JAI Press, Greenwich, CT).

White, H., 1980, A heteroskedasticity-consistent covariance matrix estimator and a direct test for heteroskedasticity, Econometrica 48, 817-838. 


\section{Appendix A}

This appendix provides our data sources for the valuation of reserves and resources, presents summary statistics on initial mine development costs, expected mine life and unit extraction costs, and concludes with an example that illustrates our valuation method.

\section{Data sources}

The valuations depend on the six well-known option pricing parameters for commodity options: the metal spot price, the volatility of the metal, the net convenience yield (convenience yield less storage costs), the risk-free rate, the strike price of the option, and the option maturity.

1. Gold and silver spot prices are from the London Bullion Market Association; the spot prices for the six base metals Aluminum, Copper, Lead, Nickel, Tin, and Zinc are from the London Metal Exchange (LME).

2. Metal price volatilities are calculated from historical spot prices using a 3-month window.

3. Net convenience yields $(y)$ are inferred from futures or forward prices and spot prices, using the standard cost-of-carry formula, $F_{t, T}=S_{t} e^{(r-y) T}$. Gold futures prices are from the COMEX, Silver futures prices are from the Chicago Board of Trade (CBT), and forward prices for the six base metals are from the LME. The inferred net convenience yield of gold is equal to the gold lease rate. $^{10}$

4. Risk-free rates are from the Federal Reserve Statistical Release H.15.

5. For the strike price of the options we use the unit extraction costs estimated based on information in firms' annual reports and 10-K statements. Please see Appendix A.2 for further details.

\footnotetext{
${ }^{10}$ The inference of convenience yields is based on 3-month forward/futures prices, since long-term commodity forwards/futures are either not available or insufficiently liquid. Since we are valuing long-term options, this implicitly assumes that the term-structure of convenience yields is flat. The gold futures curve typically has a constant slope, suggesting that this at least is a realistic assumption for gold (representing $78 \%$ of our sample).
} 
6. For the option maturity we use the expected mine life reported firms' annual reports and $10-\mathrm{K}$ statements. Please see Appendix A.3 for further details.

\section{Unit extraction costs}

SEC regulations require mining companies to disclose information about their unit extraction costs for each operating mine. There are three cost classifications: cash operating costs, total cash costs, and total production costs per unit of metal produced. Cash operating costs consist of direct mining expenses, stripping, smelting and refining expenses, and by-product credits. Total cash costs consist of cash operating costs plus royalties and production taxes. Total production costs include all cash costs plus depreciation, depletion, amortization, and projected mine closure costs. In 1996, cash operating costs accounted for about 80 percent of the total production costs. Royalties and mining taxes accounted for 3 percent, and non-cash items accounted for about 17 percent of the total costs.

We use reported total cash costs as our primary estimate of the unit extraction costs. When this information is not available, which typically happens if a mine is currently under development, we use the company's estimated future cash costs, reported in annual reports, as the best estimate of the future extraction costs. When a company does not report such cost estimates, we use a regression model to estimate cash costs based on four parameters: the mining technology - open pit versus underground mining (captured by two dummy variables), the concentration of the metal in the ground (reserve grade), the size of the ore body, and the extraction rate (defined by the ratio of annual production over reserves).

Tables A-1 and A-2 summarize the regression results and provide descriptive statistics on reported and estimated costs and other regression parameters.

Tables A-1 and A-2 about here. 
Because the sample sizes for metals other than gold are too small, cash costs are estimated only for gold reserves. For non-gold deposits, we rely on industry average cash costs. The above table shows that about half the mines are open pit, a third is underground, and the rest are a combination of open-pit and underground mines. Gold mines on average contain one million ounces of gold reserves, with grades ranging from 0.03 to 0.35 ounces per ton of ore. The median extraction rate is 14 percent of reserves per year. Over the 1989-1996 period, cash costs averaged \$256 per ounce of gold.

The regression results show that cash costs at gold producing mines are negatively related to the reserve size and the reserve grade. In addition, cash costs are non-linearly related to the extraction rate. Surprisingly, the mining technology is not a significant determinant of cash costs. We use the estimated regression coefficients to estimate cash costs for reserves and resources whenever they are missing. If for a particular mining property the actual extraction rate is zero, because the property is currently not producing, we infer the expected extraction rate from the inverse of the expected mine life. The average predicted cash costs for gold reserves and resources are \$257 and \$267 respectively, which are close to the reported cash costs of $\$ 256$.

\section{Expected mine life}

The expected mine life is defined as the number of years it takes a firm to extract its mineral reserves. Some companies report expected mine lives in their annual reports and $10-\mathrm{K}$ statements. When this information is not available, remaining mine life is calculated by dividing the total reserves with the current annual production, implicitly assuming that production remains constant throughout the life of the mine. The results from this calculation tend to be very close to the reported expected mine lives. If operations were temporarily shut down and hence annual production is unexpectedly low, we divide reserves by an adjusted production figure, which reflects how much the mine would have produced during the year had it not experienced the shutdown, i.e. adjusted production = actual production / number of months of operation $\times 12$. 
If production is zero, i.e. when a mine is currently under development, we estimate the expected mine life by regressing reported mine lives on the mining technology (open pit vs. underground) and the reserve size. The reserve size is measured as the weight of the metal bearing rock (ore) in tones. Table A3 reports the estimates from mine-life regressions across all metals.

Table A-3 about here

The results show that underground mines tend to have longer mine lives than do open-pit mines. The expected mine life increases with the size of the ore reserve. The median predicted mine life for reserve deposits is 9.83 years, which is close to the reported median mine life of nine years.

\section{Initial development costs}

We also consider whether the mines are in the production or the development stage. The major difference is that the extraction and processing facilities are already in place at producing mines while they are still under construction at development projects. We adjust the value of reserves associated with mines in the development stage further by deducting the initial development costs.

The initial development costs consist of investments in mining infrastructure (mineshafts, processing plants, roads) and mobile mining equipment. We collect the actual development costs of 42 mining projects reported in firms' annual reports that commenced production during 1989-1996. Table A-4 summarizes the average initial development costs per unit of initial reserve.

Table A-4 about here.

These estimates are consistent with Dobra (1997), who reports average initial development costs for eight open pit gold mines of $\$ 49.52$ per ounce of reserve, and development costs for underground gold mines of $\$ 76.94$ per ounce of reserve during 1989-90. Dobra further reports average initial development costs of $\$ 50.57$ per ounce of gold reserve for 24 development projects during 1991-96 


\section{Valuation of reserves and resources}

As most mining takes place sequentially, we value a mineral reserve as a portfolio of European call options with maturities ranging from one year to the expected mine life. ${ }^{11}$ We assume a constant production rate under which a mine maintains its current annual production level until the exhaustion of the deposit. Indeed we find that empirically mine extraction rates are relatively stable over time. They only vary occasionally unless the production capacity is increased or a mine experiences unexpected operational problems.

We consider only 'permitted' reserves for our valuation, i.e., reserves for which a mining permit has already been obtained. If a company operates several mines, we aggregate mine-level values to find the total value of a firm's reserves.

To illustrate our valuation technique, consider the Meikle Mine, which was one of the 14 gold mines Barrick Gold operated in 1996. Barrick's 1996 annual report provided mining statistics on the Meikle Mine summarized in Table A-5.

Table A-5 about here.

The deposit contains 6.065 million ounces of gold. Given a recovery rate of $93 \%$, only about 5.640 million ounces $(93 \%)$ are recoverable. The reported mine life of 12 years implies that on average $5,640,000 / 12=470,000 \mathrm{oz}$ of gold will be extracted annually (the current extraction rates does not provide an accurate estimate of the mine's life as 1996 was the first year of the mine's operation).

\footnotetext{
${ }^{11}$ Alternatively, we could have valued reserves as American call options assuming the entire reserve could be extracted at any time until the end of the expected mine life. This is technologically infeasible and therefore overstates the value of the reserves. However, to test the robustness of our results with respect to the valuation technique, we perform all tests using both valuation techniques. The correlation between American and European reserve values is about 0.85 . American option values tend to be about 10 to 30 percent larger than their European counterparts. None of our results depend materially on any specific valuation technique, however.
} 
A 12-year mine life suggests that this deposit can be viewed as a portfolio of 12 European call options on $470,000 \mathrm{oz}$ of gold each, with option maturities ranging from 1 to 12 years. All options have a strike price equal to the unit extraction costs of $154 \mathrm{US} \$ / \mathrm{oz}$.

Table A-6 about here.

As reported in the last column of Table A-6, the Meikle Mine had gold reserves with an aggregate value of \$1,264 million at the end of 1996.

The value of the resources can be calculated using the Hotelling principle, which values metal resources as the product of the resource size and the difference between the current metal price and the expected extraction and development costs. The expected extraction cost for gold resources is based on the regression model reported in Section A.2. This model implies that the expected extraction costs of the gold resource is US\$285.03/oz. ${ }^{12}$ The mine development costs are assumed to equal the average development costs for underground gold mines reported in Section A.4, i.e., US\$57.07/oz. Thus, we estimate the value of the gold resource of the Meikle Mine to be $992,000 \times(\$ 369.65-\$ 285.03-\$ 57.07)$ $=\$ 27.3$ million.

\footnotetext{
${ }^{12}$ For non-gold resources, we would rely on the industry average cash cost for that particular metal.
} 


\section{Appendix B}

\section{TABLE B-1. Metal Mining Firms in the Sample}

\begin{tabular}{|c|c|c|c|}
\hline 1. & Agnico-Eagle Mines Ltd. & 46. & Hanover Gold Co. \\
\hline 2. & Alaska Gold Co. & 47. & Hecla Mining Co. \\
\hline 3. & Alta Gold Co. & 48. & Homestake Mining Co. \\
\hline 4. & Amax Gold Inc. & 49. & Inmet Mining Corp. \\
\hline 5. & American Eagle Resources Inc. & 50. & International Corona \\
\hline 6. & American Resource Corp. Inc. & 51. & Kinross Gold Corp. \\
\hline 7. & Atlas Corp. & 52. & KWG Resources Inc. \\
\hline 8. & Audrey Resources Inc. & 53. & La Teko Resources Ltd. \\
\hline 9. & Aur Resources Inc. & 54. & Lac Minerals Ltd. \\
\hline 10. & Barrick Gold Corp. & 55. & MK Gold Co. \\
\hline 11. & Battle Mountain Gold & 56. & Meridian Gold Inc. (FMC Gold Co.) \\
\hline 12. & Belmoral Mines Ltd. & 57. & Miramar Mining Corp. \\
\hline 13. & Bema Gold Corp. & 58. & Newmont Gold Co. \\
\hline 14. & Bethlehem Resources Corp. & 59. & Newmont Mining Corp. \\
\hline 15. & Breakwater Resources Ltd. & 60. & North American Metals Corp. \\
\hline 16. & Caledonia Mining Corp. & 61. & North Lily Mining Co. \\
\hline 17. & Cambior Inc. & 62. & Northgate Exploration Ltd. \\
\hline 18. & Campbell Resources Inc. & 63. & Northwest Gold Corp. \\
\hline 19. & Caprock Corp. & 64. & Pan American Silver Corp. \\
\hline 20. & Casmyn Corp. & 65. & Pegasus Gold Inc. \\
\hline 21. & Clayton Sliver Mines Inc. & 66. & Piedmont Mining Co., Inc. \\
\hline 22. & Coca Mines Inc. & 67. & Placer Dome Inc. \\
\hline 23. & Coeur D’Alene Mines Corp. & 68. & Prime Resources Group Inc. \\
\hline 24. & Cominco Ltd. & 69. & Rea Gold Corp. \\
\hline 25. & Consolidated Golden Quail Resources Ltd. & 70. & Rayrock Yellowknife Resources Inc. \\
\hline 26. & Cornucopia Resources Ltd. & 71. & Real Del Monte Mining (Consol. Nevada) \\
\hline 27. & Crested Corp. & 72. & Royal Oak Mines Inc. \\
\hline 28. & Curragh Inc. & 73. & Santa Fe Pacific Gold Corp. \\
\hline 29. & Cusac Gold Mines Ltd. & 74. & Silverado Gold Mines Ltd. \\
\hline 30. & Cyprus Amax Minerals Co. & 75. & Siskon Gold Corp. \\
\hline 31. & Dakota Mining Corp. & 76. & Sonora Gold Corp. \\
\hline 32 . & Dayton Mining Corp. & 77. & Southern Peru Copper Corp. \\
\hline 33. & Dickenson Mines Ltd. & 78. & Sunshine Mining \& Refining Co. \\
\hline 34. & Echo Bay Mines Ltd. & 79. & TVX Gold Inc. \\
\hline 35. & Equinox Resources Ltd. & 80. & Teck Corp. \\
\hline 36. & Freeport-McMoran Copper \& Gold Inc. & 81. & Terra Mines Ltd. \\
\hline 37. & Galactic Resources Ltd. & 82. & USMX Inc. \\
\hline 38. & GEXA Gold Corp. & 83. & U.S. Precious Metal Inc. \\
\hline 39. & Giant Yellowknife Mines Ltd. & 84. & Vanderbilt Gold Corp. \\
\hline 40. & Goldcorp Inc. & 85. & Viceroy Resources Corp. \\
\hline 41. & Golden Cycle Gold Corp. & 86. & Vista Gold Corp. (Granges) \\
\hline 42. & Golden Knight Resources Inc. & 87. & Westmin Resources Ltd. \\
\hline 43. & Golden Star Resources Ltd. & 88. & Wharf Resources Ltd. \\
\hline 44. & Great Basin Gold Ltd. & 89. & William Resources Inc. \\
\hline 45. & Greenstone Resources Ltd. & 90. & Yuba Westgold Inc. \\
\hline
\end{tabular}


Case I

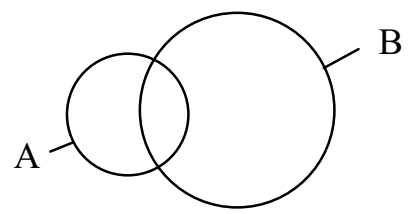

Case II

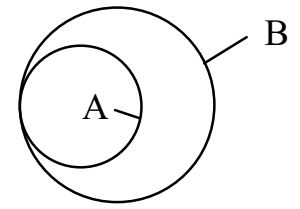

Figure I: Venn Diagrams Visualizing the Information Contents of Two Proxy Variables A and B. The size of each circle represents the information quantity of each proxy. The location of each circle represents the information quality of each proxy. 